\title{
Post partum presentation of hypercalcaemic sarcoidosis
}

\author{
N. Wilson-Holt
}

Whittington Hospital, London N19 5NF, UK.

\begin{abstract}
Summary: A number of corticosteroid responsive diseases have been shown to undergo exacerbation in the puerperium. The presentation of a woman 8 weeks after delivery with severe hypercalcaemia, a highly steroid sensitive feature of sarcoidosis, adds to the evidence that sarcoidosis can also be numbered amongst such diseases with relapse in the puerperium.
\end{abstract}

\section{Case report}

A 28 year old Caucasian woman presented in September 1983 with a 6 week history of malaise, depression, anorexia, vomiting, constipation and weight loss. She also complained of generalized arthralgia, and had developed a dry cough. All these symptoms had developed since the birth of her third child 8 weeks previously in July 1983 . Her previous health had been good and she had not taken vitamin D supplements during the pregnancy. Physical examination was unremarkable.

Investigations on admission revealed hypercalcaemia $\left(\mathrm{Ca}^{2+} 3.77 \mathrm{mmol} / 1\right.$, albumin $41 \mathrm{~g} / 1, \mathrm{PO}_{4} 1.36$ $\mathrm{mmol} / 1)$. Alkaline phosphatase was 59 IU. The serum urea was $8.0 \mathrm{mmol} / 1$, and the serum creatinine $60 \mu \mathrm{mol} / 1$. Erythrocyte sedimentation rate was $52 \mathrm{~mm}$ in the first hour and the serum globulins were raised. 25 -hydroxy vitamin $D$ was normal at $10.5 \mathrm{ng} / \mathrm{ml}$, and the parathyroid hormone was within normal limits at $50 \mathrm{pg} / \mathrm{ml}$. Serum angiotensin converting enzyme was elevated at $111 \mathrm{mmol} / \mathrm{min} / \mathrm{ml}$. Chest X-ray revealed widespread miliary shadowing involving both lung fields.

A clinical diagnosis of sarcoidosis was made and, in view of the severity of the hypercalcaemia, the patient was commenced on treatment with prednisolone without a tissue diagnosis. This led to speedy clinical improvement and a fall in the serum calcium concentration to normal. Clinical improvement was accompanied by resolution of the miliary shadowing on the chest X-ray, and normalization of the serum angiotensin converting enzyme concentration. On a reduced dose of prednisolone she remained well. The sarcoidosis has not relapsed after several months off all therapy.

\section{Discussion}

A beneficial effect of pregnancy on sarcoidosis was first reported by Berman (1951). In a study of 16 pregnancies in sarcoidosis patients Maycock et al. (1957) observed that pregnancy appeared to have an ameliorating effect on sarcoidosis during the pre-natal period but that this benefit is frequently lost after delivery. Furthermore, 4 patients in their series developed new manifestations of sarcoidosis in the puerperium, namely skin papules, leucopenia, parotid enlargement, hepatosplenomegaly and haemolytic anaemia.

The phenomenon of relapse in the puerperium is also a feature of other diseases which are known to be corticosteroid responsive, including rheumatoid arthritis (Hench, 1938), autoimmune thyroid disease (Amino et al., 1977), myasthenia gravis (Fraser \& Turner, 1953) and inflammatory bowel disease (Fielding \& Cooke, 1970). However, the underlying mechanisms remain unclear.

The concentration of a pregnancy-associated alpha2-glycoprotein rises to very high levels during gestation in most normal women. This protein has immunosuppressive properties and Unger et al. (1983) have suggested that high concentrations of pregnancyassociated glycoprotein may be associated with remission of rheumatoid arthritis in pregnancy. Such a mechanism may also be applicable to other diseases including sarcoidosis. 


\section{References}

BERMAN, R.H. (1951). Sarcoidosis benefitted by pregnancy; report of case. Journal of the American Medical Association, 147, 246.

MAYCOCK, R.L., SULLIVAN, R.D., GREENING, R.R. \& JONES, R. (1957). Sarcoidosis and pregnancy. Journal of the American Medical Association, 164, 158.

HENCH, P.S. (1938). The ameliorating effect of pregnancy on chronic atrophic (infectious rheumatoid) arthritis, fibrositis and intermittent hydrarthrosis. Mayo Clinic Proceedings, 13, 161.

AMINO, N., MIYAI, K., YAMAMOTO, T., KURO, R., TANAKA, F., TANIZAWA, O. \& KUMAHARA, Y. (1977).
Transient recurrence of hyperthyroidism after delivery in Graves' disease. Journal of Clinical Endocrinology and Metabolism, 44, 130.

FRASER, D. \& TURNER, J.W.A. (1953). Myasthenia gravis and pregnancy. Lancet, ii, 417.

FIELDING, J.F. \& COOKE, W.T. (1970). Pregnancy and Crohn's disease. British Medical Journal, 2, 76.

UNGER, A., KAY, A., GRIFFIN, A. \& PANAYI, G. (1983). Disease activity and pregnancy associated alpha 2 glycoprotein in rheumatoid arthritis during pregnancy. British Medical Journal, 286, 750. 